\title{
UPAYA MENINGKATKAN PRESTASI BELAJAR IPA DENGAN METODE PEMBELAJARAN PENEMUAN (DISCOVERY) PADA SISWA KELAS VI SDN 1 MENDAWAI
}

Efforts To Improve Ipa Learning Achievement With Discovery Learning Method In Grade VI Students Of SDN 1 Mendawai

Hartatik

SDN I Mendawai, Katingan, Kalimantan Tengah, Indonesia

\section{ARTIKEL INFO \\ Diterima Januari 2020}

Dipublikasi Maret 2020

*e-mail :

Orcid :

\section{ABSTRAK}

Penelitian ini dilatar belakangi oleh rendahnya prestasi belajar IPA pada siswa kelas VI SDN I Mendawai. Jenis penelitian ini adalah penelitian tindakan yang mengharuskan peneliti untuk berpartisipasi dan berkolaborasi antara peneliti dan kelompok sasaran. Subjek penelitian ini adalah siswa kelas VI SDN I Mendawai. Instrumen penelitian yaitu silabus, rencana pembelajaran, lembar kegiatan siswa, lembar observasi kegiatan belajar mengajar dan tes formatif. Teknik analisis data menggunakan Teknik analisis deskriptif kualitatif. Hasil penelitian siklus I $(67,85 \%)$, siklus II $(78,57 \%)$ dan siklus III $(89,28 \%)$. Penerapan metode pembelajaran penemuan (discovery) mempunyai pengaruh positif.

Kata kunci: Prestasi Belajar IPA, Metode Pembelajaran Penemuan (Discovery).

\begin{abstract}
This research is motivated by the low achievement of natural science learning in grade VI students of SDN I Mendawai. This type of research is action research that requires researchers to participate and collaborate between researchers and the target group. The subjects of this study were students of grade VI SDN I Mendawai. The research instruments were syllabus, lesson plans, student activity sheets, observation sheets of teaching and learning activities and formative tests. Data analysis techniques using qualitative descriptive analysis techniques. The results of the study cycle I (67.85\%), cycle II (78.57\%) and cycle III (89.28\%). The application of discovery learning methods has a positive effect.
\end{abstract}

Keywords: Natural Science Learning Achievement, Discovery Learning Method. 


\section{PENDAHULUAN}

Sistem pendidikan di Indonesia ternyata telah mengalami banyak perubahan. Perubahan-perubahan itu terjadi karena telah dilakukan berbagai usaha pembaharuan dalam pendidikan. Akibat pengaruh itu pendidikan semakin mengalami kemajuan.

Sejalan dengan kemajuan tersebut, maka dewasa ini pendidikan di sekolahsekolah telah menunjukkan perkembangan yang sangat pesat. Perkemangan itu terjadi karena terdorong adanya pembaharuan tersebut, sehingga di dalam pengajaranpun guru selalu ingin menemukan metode dan peralatan baru yang dapat memberikan semangat belajar bagi murid-murid. Bahkan secara keseluruhan dapat dikatakan bahawa pembaharuan dalam system pendidikan yang mencakup seluruh komponen yang ada. Pembangunan di bidang pendidikan barulah ada artinya apabila dalam pendidiakn dapat dimanfaatkan sesuai dengan kebutuhan masyarakat dan bangsa Indonesia yang sedang membangun.

Berdasarkan pengalaman penulis di lapangan, kegagalan dalam belajar rata-rata dihadapi oleh sejumlah siswa yang tidak memiliki dorongan belajar. Untuk itu dibutuhkan suatu kegiatan yang dilakukan oleh guru dengan upaya membangkitkan motivasi belajar siswa, misalnya dengan membimbing siswa untuk terlibat langsung dalam kegiatan yang melibatkan siswa serta guru yang berperan sebagai pembimbing untuk menemukan konsep IPA.

Motivasi tidak hanya menjadikan siswa terlibat dalam kegiatan akademik, motivasi juga penting dalam menentukan seberapa jauh siswa akan belajar dari suatu kegiatan pembelajaran atau seberapa jauh menyerap informasi yang disajikan kepada mereka. Siswa yang termotivasi untuk belajar sesuatu akan menggunakan proses kognitif yang lebih tinggi dalam mempelajari materi itu, sehingga siswa itu akan meyerap dan mengendapan materi itu dengan lebih baik. Tugas penting guru adalah merencanakan bagaimana guru mendukung motivasi siswa (Nur, 200I: 3). Untuk itu sebagai seorang guru disamping menguasai materi, juga diharapkan dapat menetapkan dan melaksanakan penyajian materi yang sesuai kemampuan dan kesiapan anak, sehingga menghasilkan penguasaan materi yang optimal bagi siswa.

Proses belajar mengajar IPA meliputi kegiatan yang dilakukan guru mulai dari perencanaan, pelaksanaan kegiatan sampai evaluasi dan program tindak lanjut yang berlangsung dalam situasi edukatif untuk mencapai tujuan tertentu yaitu pengajaran IPA.

Penggunaan teknik discovery ini guru berusaha meningkatkan aktivitas siswa dalam proses belajar mengajar yang memiliki keuntungan yaitu:

I. Mampu membantu siswa untuk mengembangkan, memperbanyak kesiapan, serta penguasaan keterampilan dalam proses kognitif/pengenalan siswa.

2. Siswa dapat memperoleh pengetahuan sifatnya individual sehingga dapat kokoh/mendalam tertinggal dalam jiwa siswa tersebut.

3. Mampu meningkatkan gairah belajar mengajar para siswa.

4. Memberikan kesempatan kepada siswa untuk berkembang dan maju sesuai dengan potensi dirinya masing-masing.

5. Mengarahkan cara siswa belajar, sehingga lebih memiliki motivasi yang lebih untuk belajar lebih giat.

6. Membantu siswa untuk meningkatkan rasa percaya diri dalam proses penemuan sendiri.

Prestasi belajar yang dicapai oleh siswa dengan melibatkan seluruh potensi yang dimilikinya setelah siswa itu melakukan kegiatan belajar. Pencapaian hasil belajar tersebut dapat diketahui dengan megadakan penilaian tes hasil belajar. Penilaian diadakan untuk mengetahui sejauh mana siswa telah 
berhasil mengikuti pelajaran yang diberikan oleh guru. $\mathrm{Di}$ samping itu guru dapat mengetahui sejauh mana keberhasilan guru dalam proses belajar mengajar di sekolah.

Sejalan dengan prestasi belajar, maka dapt diartikan bahwa prestasi belajar IPA adalah nilai yang dipreoleh siswa setelah melibatkan secara langsung/aktif seluruh potensi yang dimilikinya baik aspek kognitif (pengetahuan), afektif (sikap) dan psikomotor (keterampilan) dalam proses belajar mengajar IPA. Adanya motivasi dalam pembelajaran model penemuan (discovery) tersebut maka hasil-hasil belajar akan menjadi optimal. Makin tepat motivasi yang diberikan, akan makin berhasil pula pelajaran itu. Dengan motivasi yang tinggi maka intensitas usaha belajar siswa akan tingi pula. Jadi motivasi akan senantiasa menentukan intesitas usaha belajar siswa. Hasil ini akan dapat meningkatkan prestasi belajar siswa.

\section{METODOLOGI PENELITIAN}

Metodologi penelitian yang digunakan adalah penelitian tindakan yang berarti penelitian mengenai hal-hal yang terjadi dimasyarakat atau sekolompok sasaran, dan hasilnya langsung dapat dikenakan pada masyarakat yang bersangkutan.

Ciri atau karakteristik utama dalam penelitian tindakan adalah adanya partisipasi dan kolaborasi antara peneliti dengan anggota kelompok sasaran. Penelitian tidakan adalah satu strategi pemecahan masalah yang memanfaatkan tindakan nyata dalam bentuk proses pengembangan invovatif yang dicoba sambil jalan dalam mendeteksi dan memecahkan masalah. Dalam prosesnya pihak-pihak yang terlibat dalam kegiatan tersebut dapat saling mendukung satu sama lain.

Penelitian ini dilaksanakan melalui 5 tahap, yaitu tahap perencanaan, tahap persiapan, tahap pelaksanaan, tahap pengolahan data, dan penyusunan Laporan.
Instrumen yang digunakan dalam penelitian ini adalah silabus, rencana pembelajaran, lembar kegiatan siswa, lembar observasi kegiatan belajar mengajar dan tes formatif.

Analisis deskriptif kualitatif adalah Teknik analisis data yang digunakan dalam penelitian ini dengan tujuan untuk mengetahui prestasi belajar yang dicapai siswa juga untuk memperoleh respon siswa terhadap kegiatan pembelajaran serta aktivitas siswa selama proses pembelajaran.

\section{HASIL DAN PEMBAHASAN}

\section{A. Analisis Data Penelitian Persiklus}

I. Siklus I

Tabel I Pengelolan Pembelajaran Pada Siklus I

\begin{tabular}{|c|c|c|c|c|}
\hline \multirow{2}{*}{ No } & \multirow{2}{*}{ Aspek yang diamati } & \multicolumn{2}{|c|}{$\begin{array}{l}\text { Penilaia } \\
\mathrm{n}\end{array}$} & \multirow{2}{*}{$\begin{array}{l}\text { Rat } \\
\text { a- } \\
\text { rata }\end{array}$} \\
\hline & & PI & $\mathrm{P} 2$ & \\
\hline \multirow{6}{*}{ I } & $\begin{array}{l}\text { Pengamatan KBM } \\
\text { A. Pendahuluan } \\
\text { I. Memotivasi siswa } \\
\text { 2. Menyampaikan } \\
\text { pembelajaran }\end{array}$ & $\begin{array}{l}3 \\
1\end{array}$ & $\begin{array}{l}2 \\
2\end{array}$ & $\begin{array}{l}2,5 \\
1,5\end{array}$ \\
\hline & $\begin{array}{l}\text { B. Kegiatan Inti } \\
\text { I. Mendiskusikan langkah-langkah } \\
\text { kegiatan bersama siswa }\end{array}$ & $\begin{array}{l}3 \\
3\end{array}$ & $\begin{array}{l}3 \\
3\end{array}$ & $\begin{array}{l}3 \\
3\end{array}$ \\
\hline & $\begin{array}{l}\text { 2. Membimbing siswa melakukan } \\
\text { kegiatan }\end{array}$ & 3 & 3 & 3 \\
\hline & $\begin{array}{l}\text { 3. Membimbing siswa mendiskusikan } \\
\text { hasil kegiatan dalam kelompok }\end{array}$ & 3 & 3 & 3 \\
\hline & $\begin{array}{l}\text { 4. Memberikan kesempatan pada } \\
\text { siswa untuk mempresentasikan } \\
\text { hasil kegiatan belajar mengajar } \\
\text { 5. Membimbing siswa merumuskan } \\
\text { kesimpulan/menemukan konsep }\end{array}$ & 3 & 3 & 3 \\
\hline & $\begin{array}{l}\text { C. Penutup } \\
\text { I. Membimbing siswa membuat } \\
\text { rangkuman } \\
\text { 2. Memberikan evaluasi }\end{array}$ & $\begin{array}{l}3 \\
3\end{array}$ & $\begin{array}{l}3 \\
3\end{array}$ & $\begin{array}{l}3 \\
3\end{array}$ \\
\hline II & Pengelolaan Waktu & 2 & 2 & 2 \\
\hline III & $\begin{array}{cc}\text { Antusiasme Kelas } \\
\text { I. Siswa Antusias } \\
\text { 2. } \quad \text { Guru Antusias }\end{array}$ & $\begin{array}{l}3 \\
3\end{array}$ & $\begin{array}{l}3 \\
3\end{array}$ & $\begin{array}{l}3 \\
3\end{array}$ \\
\hline & Jumlah & $\begin{array}{l}3 \\
1\end{array}$ & 31 & 31 \\
\hline
\end{tabular}


Jurnal Bimbingan dan Konseling

$\begin{array}{ccl}\text { Keterangan } & \text { Nilai } & \text { : Kriteria } \\ & 1 & : \text { Tidak Baik } \\ 2 & : \text { Kurang Baik } \\ & 3 & : \text { Cukup Baik } \\ & 4 & : \text { Baik }\end{array}$

Tabel 2 Aktivitas Guru Dan Siswa Pada Siklus I

\begin{tabular}{|c|l|c|}
\hline No & Aktivitas Guru yang diamati & $\begin{array}{c}\text { Persent } \\
\text { ase }\end{array}$ \\
\hline I & Menyampaikan tujuan & 6.67 \\
2 & Memotivasi siswa/merumuskan & 10.00 \\
3 & masalah & 8.33 \\
4 & Mengkaitkan dengan pelajaran & 5.00 \\
5 & berikutnya & 18.33 \\
6 & Menyampaikan materi/langkah- & 20.00 \\
7 & langkah/strategi & 10.00 \\
8 & Menjelaskan materi yang sulit & 15.00 \\
9 & Membimbing dan mengamati & 6.67 \\
& siswa dalam menemukan konsep & \\
& Meminta siswa menyajikan dan & \\
& mendiskusikan hasil kegiatan & \\
& Memberikan umpan balik & \\
& Membimbing siswa merangkum & \\
\hline $\mathrm{N}$ & pelajaran & \\
\hline & Aktivitas Siswa yang diamati & Persent \\
\hline $\mathrm{I}$ & Mendengarkan/memperhatikan & ase \\
2 & penjelasan guru & 12.63 \\
3 & Membaca buku siswa & 18.75 \\
4 & Bekerja dengan sesama anggota & 14.38 \\
5 & kelompok siswa & 3.96 \\
6 & Diskusi antar siswa/antara s.25 \\
7 & dengan guru & 8.75 \\
9 & Menyajikan hasil pembelajaran & 6.88 \\
& Mengajukan/menanggapi & 8.13 \\
& Pertanyaan/ide & \\
& Menulis yang relevan dengan KBM & \\
\hline
\end{tabular}

Tabel 3 Rekapitulasi Hasil Tes Siklus I

\begin{tabular}{|c|l|c|}
\hline No & \multicolumn{1}{|c|}{ Uraian } & $\begin{array}{c}\text { Hasil } \\
\text { Siklus I }\end{array}$ \\
\hline I & Nilai rata-rata tes formatif & 70,00 \\
2 & Jumlah siswa yang tuntas belajar & 19 \\
3 & Persentase ketuntasan belajar & 67,85 \\
\hline
\end{tabular}

2. Siklus II

Tabel 4.4. Pengelolaan Pembelajaran Pada Siklus II

\begin{tabular}{|c|c|c|c|c|c|}
\hline \multirow{2}{*}{ No } & \multirow{2}{*}{\multicolumn{2}{|c|}{ Aspek yang diamati }} & \multicolumn{2}{|c|}{ Penilaian } & \multirow{2}{*}{$\begin{array}{l}\text { Rata } \\
\text {-rata }\end{array}$} \\
\hline & & & \multicolumn{2}{|c|}{\begin{tabular}{l|l}
$\mathrm{PI}$ & $\mathrm{P} 2$
\end{tabular}} & \\
\hline \multirow{28}{*}{ I } & \multicolumn{2}{|c|}{ Pengamatan KBM } & \multirow{4}{*}{$\begin{array}{l}3 \\
3\end{array}$} & \multirow{4}{*}{$\begin{array}{l}3 \\
3\end{array}$} & \multirow{4}{*}{$\begin{array}{l}3 \\
3\end{array}$} \\
\hline & \multirow{3}{*}{ A. } & Pendahuluan & & & \\
\hline & & Memotivasi siswa & & & \\
\hline & & $\begin{array}{l}\text { Menyampaikan } \\
\text { tujuan pembelajaran }\end{array}$ & & & \\
\hline & \multicolumn{2}{|c|}{ B. Kegiatan Inti } & \multirow{4}{*}{$\begin{array}{l}3 \\
4\end{array}$} & \multirow[b]{2}{*}{3} & \multirow[b]{2}{*}{3} \\
\hline & I. & Mendiskusikan & & & \\
\hline & & langkah-langkah & & 4 & 4 \\
\hline & & kegiatan bersama & & \multirow{2}{*}{4} & \multirow{2}{*}{4} \\
\hline & & siswa & 4 & & \\
\hline & \multicolumn{2}{|c|}{$\begin{array}{l}\text { 2. Membimbing siswa } \\
\text { melakukan kegiatan }\end{array}$} & 4 & 4 & 4 \\
\hline & & Membimbing siswa & \multirow[t]{13}{*}{3} & \multirow[t]{13}{*}{3} & 3 \\
\hline & & kegiatan dalam & & & \\
\hline & & kelompok & & & \\
\hline & & Memberikan & & & \\
\hline & & kesempatan pada & & & \\
\hline & & siswa untuk & & & \\
\hline & & mempresentasikan & & & \\
\hline & & hasil kegiatan & & & \\
\hline & & belajar mengajar & & & \\
\hline & 5 . & Membimbing siswa & & & \\
\hline & & merumuskan & & & \\
\hline & & kesimpulan/menem & & & \\
\hline & & ukan konsep & & & \\
\hline & C. $\mathrm{Pe}$ & utup & & & \\
\hline & I. & Membimbing siswa & 3 & 4 & 3,5 \\
\hline & & membuat & 4 & 4 & 4 \\
\hline & & rangkuman & & & \\
\hline & 2. & $\begin{array}{l}\text { Memberikan } \\
\text { evaluasi }\end{array}$ & & & \\
\hline II & Pengel & an Waktu & 3 & 3 & 2 \\
\hline & Antusi & ne Kelas & & & \\
\hline III & I. & Siswa Antusias & 4 & 3 & 3,5 \\
\hline & & Guru Antusias & 4 & 4 & 4 \\
\hline & & umlah & 42 & 42 & 42 \\
\hline
\end{tabular}

$\begin{array}{ccl}\text { Keterangan } & \text { Nilai } & \text { : Kriteria } \\ & 1 & : \text { Tidak Baik } \\ 2 & \text { : Kurang Baik } \\ & 3 & \text { : Cukup Baik } \\ & 4 & \text { : Baik }\end{array}$


Tabel 5 Aktivitas Guru Dan Siswa Pada Siklus II

\begin{tabular}{|c|c|c|}
\hline No & Aktivitas Guru yang diamati & $\begin{array}{l}\text { Persenta } \\
\text { se }\end{array}$ \\
\hline $\mathrm{I}$ & Menyampaikan tujuan & 6.67 \\
\hline 2 & \multirow{2}{*}{$\begin{array}{l}\text { Memotivasi siswa/merumuskan } \\
\text { masalah }\end{array}$} & 6.67 \\
\hline 3 & & 6.67 \\
\hline 4 & \multirow{2}{*}{$\begin{array}{l}\text { Mengkaitkan dengan pelajaran } \\
\text { berikutnya }\end{array}$} & 11.67 \\
\hline 5 & & 11.67 \\
\hline 6 & \multirow{2}{*}{$\begin{array}{l}\text { Menyampaikan materi/langkah- } \\
\text { langkah/strategi }\end{array}$} & 25.00 \\
\hline 7 & & 8.33 \\
\hline 8 & \multirow{2}{*}{$\begin{array}{l}\text { Menjelaskan materi yang sulit } \\
\text { Membimbing dan mengamati siswa } \\
\text { dalam menentukan konsep }\end{array}$} & 16.67 \\
\hline 9 & & 6.67 \\
\hline & $\begin{array}{l}\text { Meminta siswa menyajikan dan } \\
\text { mendiskusikan hasil kegiatan } \\
\text { Memberikan umpan balik }\end{array}$ & \\
\hline & \multicolumn{2}{|l|}{$\begin{array}{l}\text { Membimbing siswa merangkum } \\
\text { pelajaran }\end{array}$} \\
\hline No & Aktivitas Siswa yang diamati & $\begin{array}{l}\text { Persenta } \\
\text { se }\end{array}$ \\
\hline I & \multirow{2}{*}{$\begin{array}{l}\text { Mendengarkan/memperhatikan } \\
\text { penjelasan guru }\end{array}$} & 17.91 \\
\hline 2 & & 14.16 \\
\hline 3 & Membaca buku siswa & 19.79 \\
\hline 4 & \multirow{2}{*}{$\begin{array}{l}\text { Bekerja dengan sesama anggota } \\
\text { kelompok }\end{array}$} & 13.96 \\
\hline 5 & & 5.00 \\
\hline 6 & \multirow{2}{*}{$\begin{array}{l}\text { Diskusi antar siswa/antara siswa } \\
\text { dengan guru }\end{array}$} & 5.63 \\
\hline 7 & & 7.50 \\
\hline 8 & Menyajikanhasil pembelajaran & 6,67 \\
\hline 9 & \multirow{4}{*}{$\begin{array}{l}\text { Mengajukan/menanggapi } \\
\text { pertanyaan/ide } \\
\text { Menulis yang relevan dengan KBM } \\
\text { Merangkum pembelajaran } \\
\text { Mengerjakan tes evaluasi/latihan }\end{array}$} & 9.38 \\
\hline & & \\
\hline & & \\
\hline & & \\
\hline
\end{tabular}

Tabel 6 Rekapitulasi Hasil Tes Siklus II

\begin{tabular}{|c|l|c|}
\hline No & \multicolumn{1}{|c|}{ Uraian } & $\begin{array}{c}\text { Hasil } \\
\text { Siklus II }\end{array}$ \\
\hline I & $\begin{array}{l}\text { Nilai rata-rata tes formatif } \\
2\end{array}$ & $\begin{array}{l}\text { Jumlah siswa yang tuntas } \\
\text { belajar }\end{array}$ \\
3 & $\begin{array}{l}\text { Persentase ketuntasan } \\
\text { belajar }\end{array}$ & 78,57 \\
\hline
\end{tabular}

3. Siklus III

Tabel 7 Pengelolaan Pembelajaran

Pada Siklus III

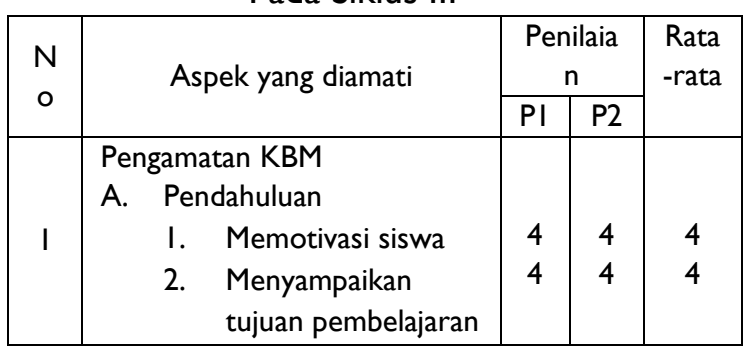

\begin{tabular}{|c|c|c|c|c|c|}
\hline & & $\begin{array}{l}\text { Kegiatan Inti } \\
\text { I. } \\
\text { Mendiskusikan } \\
\text { langkah-langkah } \\
\text { kegiatan bersama } \\
\text { siswa } \\
\text { 2. Membimbing siswa } \\
\text { melakukan kegiatan } \\
\text { 3. Membimbing siswa } \\
\text { mendiskusikan hasil } \\
\text { kegiatan dalam } \\
\text { kelompok } \\
\text { Memberikan } \\
\text { kesempatan pada } \\
\text { siswa untuk } \\
\text { mempresentasikan } \\
\text { hasil kegiatan } \\
\text { belajar mengajar } \\
\text { Membimbing siswa } \\
\text { merumuskan } \\
\text { kesimpulan/menem } \\
\text { ukan konsep }\end{array}$ & $\begin{array}{l}4 \\
4\end{array}$ & $\begin{array}{l}4 \\
4 \\
4 \\
4\end{array}$ & $\begin{array}{l}4 \\
4\end{array}$ \\
\hline & C. & 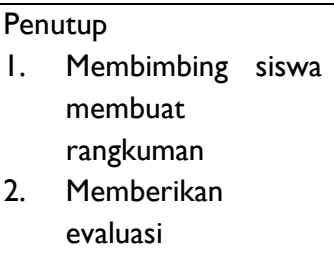 & $\begin{array}{l}3 \\
4\end{array}$ & $\begin{array}{l}4 \\
4\end{array}$ & $\begin{array}{c}3,5 \\
4\end{array}$ \\
\hline II & Peng & elolaan Waktu & 3 & 3 & 3 \\
\hline III & Anti & \begin{tabular}{l}
\multicolumn{2}{l}{ ssiasme Kelas } \\
I. $\quad$ Siswa Antusias \\
2. $\quad$ Guru Antusias
\end{tabular} & $\begin{array}{l}4 \\
4\end{array}$ & $\begin{array}{l}3 \\
4\end{array}$ & $\begin{array}{c}3,5 \\
4\end{array}$ \\
\hline & & Jumlah & $\begin{array}{l}4 \\
5\end{array}$ & 45 & 45 \\
\hline
\end{tabular}

$\begin{array}{ccl}\text { Keterangan } & : \text { Nilai } & \text { : Kriteria } \\ & 1 & : \text { Tidak Baik } \\ & 2 & \text { : Kurang Baik } \\ & 3 & \text { : Cukup Baik } \\ & 4 & \text { : Baik }\end{array}$


Jurnal Bimbingan dan Konseling

Tabel 4.8 Aktivitas Guru Dan Siswa Pada Siklus Itterhadap materi yang disampaikan guru

\begin{tabular}{|c|c|c|}
\hline No & Aktivitas Guru yang diamati & $\begin{array}{l}\text { Persenta } \\
\text { se }\end{array}$ \\
\hline I & Menyampaikan tujuan & 6.67 \\
\hline 2 & Memotivasi siswa/merumuskan & 6.67 \\
\hline 3 & masalah & 10.00 \\
\hline 4 & Mengkaitkan dengan pelajaran & 13.33 \\
\hline 5 & berikutnya & 10.00 \\
\hline 6 & Menyampaikan materi/langkah- & 21.67 \\
\hline 7 & langkah/strategi & 10.00 \\
\hline 8 & Menjelaskan materi yang sulit & 11.67 \\
\hline 9 & $\begin{array}{l}\text { Membimbing dan mengamati } \\
\text { siswa dalam menentukan konsep } \\
\text { Meminta siswa menyajikan dan } \\
\text { mendiskusikan hasil kegiatan } \\
\text { Memberikan umpan balik } \\
\text { Membimbing siswa merangkum } \\
\text { pelajaran }\end{array}$ & 10.00 \\
\hline No & Aktivitas Siswa yang diamati & $\begin{array}{c}\text { Persenta } \\
\text { se }\end{array}$ \\
\hline 1 & Mendengarkan/memperhatikan & 19.38 \\
\hline 2 & penjelasan guru & 13.96 \\
\hline 3 & Membaca buku siswa & 20.21 \\
\hline 4 & Bekerja dengan sesama anggota & 14.58 \\
\hline 5 & kelompok & 5.21 \\
\hline 6 & Diskusi antar siswa/antara siswa & 5.42 \\
\hline 7 & dengan guru & 6.25 \\
\hline 8 & Menyajikan hasil pembelajaran & 7.29 \\
\hline 9 & $\begin{array}{l}\text { Mengajukan/menanggapi } \\
\text { pertanyaan/ide } \\
\text { Menulis yang relevan dengan } \\
\text { KBM } \\
\text { Merangkum pembelajaran } \\
\text { Mengerjakan tes evaluasi/latihan }\end{array}$ & 7.71 \\
\hline
\end{tabular}

Tabel 4.9. Rekapitulasi Hasil Tes Siklus III

\begin{tabular}{|c|l|c|}
\hline No & \multicolumn{1}{|c|}{ Uraian } & $\begin{array}{c}\text { Hasil } \\
\text { Siklus III }\end{array}$ \\
\hline I & Nilai rata-rata & 89,28 \\
2 & tes formatif & 25 \\
3 & Jumlah siswa & 89,28 \\
& yang tuntas & \\
& belajar & \\
& $\begin{array}{l}\text { Persentase } \\
\text { ketuntasan } \\
\text { belajar }\end{array}$ \\
\hline
\end{tabular}

\section{Ketuntasan Hasil belajar Siswa}

Melalui hasil peneilitian ini menunjukkan bahwa pembelajaran penemuan (discovery) memiliki dampak positif dalam meningkatkan prestasi belajar siswa. Hal ini dapat dilihat dari semakin mantapnya pemahaman siswa

(ketuntasan belajar meningkat dari sklus I, II, dan II) yaitu masing-masing 67,85\%, 78,57\%, dan $89,28 \%$. Pada siklus III ketuntasan belajar siswa secara klasikal telah tercapai.

\section{Kemampuan Guru dalam Mengelola Pembelajaran}

Berdasarkan analisis data, diperoleh aktivitas siswa dalam proses pembelajaran penemuan (discovery) dalam setiap siklus mengalami peningkatan. Hal ini berdampak positif terhadap prestasi belajar siswa yaitu dapat ditunjukkan dengan meningkatnya nilai rata-rata siswa pada setiap siklus yang terus mengalami peningkatan.

\section{Aktivitas Guru dan Siswa Dalam Pembelajaran}

Berdasarkan analisis data, diperoleh aktivitas siswa dalam proses pembelajaran IPA pada pokok bahasan faktor-faktor yang mempengaruhi keseimbangan ekosistem dengan metode pembelajaran penemuan (discovery) yang paling dominan adalah bekerja dengan menggunakan alat/media, mendengarkan/ memperhatikan penjelasan guru, dan diskusi antar siswa/antara siswa dengan guru. Jadi dapat dikatakan bahwa aktivitas siswa dapat dikategorikan aktif.

Sedangkan untuk aktivitas guru selama pembelajaran telah melaksanakan langahlangkah pembelajaran penemuan (discovery) dengan baik. Hal ini terlihat dari aktivitas guru yang muncul di antaranya aktivitas membimbing dan mengamati siswa dalam mengerjakan kegiatan LKS/menemukan konsep, menjelaskan/melatih menggunakan alat, memberi umpan balik/evaluasi/tanya jawab dimana prosentase untuk aktivitas di atas cukup besar.

\section{KESIMPULAN}

Dari hasil kegiatan pembelajaran yang telah dilakukan selama tiga siklus, dan berdasarkan seluruh pembahasan serta analisis yang telah dilakukan dapat disimpulkan sebagai berikut:

I. Pembelajaran dengan penemuan 
Jurnal Bimbingan dan Konseling

(discovery) memiliki dampak positif dalam meningkatkan prestasi belajar siswa yang ditandai dengan peningkatan ketuntasan belajar siswa dalam setiap siklus, yaitu siklus I (67,85\%), siklus II (78,57\%), siklus III $(89,28 \%)$.

2. Penerapan metode pembelajaran penemuan (discovery) mempunyai pengaruh positif, yaitu dapat meningkatkan motivasi belajar siswa yang ditunjukan dengan hasil wawancara dengan sebagian siswa, ratarata jawaban siswa menyatakan bahwa siswa tertarik dan berminat dengan metode pembelajaran penemuan (discovery) sehingga mereka menjadi termotivasi untuk belajar.

\section{DAFTAR PUSTAKA}

Abdul, Majid. 2013. Perencanaan Pembelajaran Mengembangkan Standar Kompetensi Guru. Bandung: PT. Remaja Rosda Karya

Diplan \& Andi Setiawan. 2018. Penelitian Tindakan Kelas. Yogyakarta: DEEPUBLISH.

Fatchurahman, M, dkk. 2017. The Implementation Of Guidance And Counselling In SMA (Senior High) Government School In Palangkaraya. Jurnal Konseling Gusjijang, 3(I):20-48.

Hamdani. 20II. Strategi Belajar Mengajar. Bandung: Pustaka Setia.

Nurhidayati, Diana Dwi. 2016. Peningkatan Pemahaman Manajanemen Waktu Melalui Bimbingan Kelompok dengan Teknik Problem Solving. Jurnal Psikopedagogia. Vol. 5, no. I

Prayitno, dkk. 2017. Layanan Bimbingan Kelompok dan Konseling Kelompok. Bogor: Ghalia Indonesia.

Prayitno. 2013. Dasar-Dasar Bimbingan dan Konseling. Jakarta: Rineka Cipta.

Riadin, Agung \& Cici Liani Fitriani. 2018. Upaya Meningkatkan Hasil Belajar Ipa
Menggunakan Model Pembelajaran Kooperatif Tipe Jigsaw Dengan Berbantuan Media Alat Peraga Konkret Pada Peserta Didik Kelas V SDN-4 Kasongan Baru Tahun Pelajaran 2016/2017. Pedagogik: Jurnal Pendidikan, I3(2): I-5

Riadin, Agung. 2015. Penerapan Pembelajaran Ipa Terpadu Model Keterhubungan (Connected) Pada Pokok Bahasan Kalor Dan Pemisahan Campuran Siswa Kelas VII Semester II MTsn I Model Palangka Raya. Pedagogik Jurnal Pendidikan, I0(2):87I 00.

Setyawan, Dedy. 20I5. Penerapan Metode

Discovery Untuk Menigkatkan Hasil Belajar Ipa Pada Peserta Didik Kelas V Sdn 3 Selat Hilir Kabupaten Kapuas Tahun Pelajaran 20I4/20I5. Pedagogik: Jurnal Pendidikan, 10(2):55-58.

Shoimin, Aris. 2014. 68 Model Pembelajaran Inovatif Dalam Kurikulum 2013. Yogyakarta. Ar-Ruzz Media.

Sugiyono. 2015. Metode Penelitian Pendidikan. Bandung: Alfabeta

Sugiyono. 2017. Metode Penelitian Pendidikan. Bandung: Alfabeta

Wahab, Rohmalina. 20I5. Psikologi Belajar. Jakarta: Rajawali Pers. 